\title{
Current perspectives in the management of patients with drug-induced osteonecrosis of the maxilla: experience of the school of Naples Federico II
}

\author{
S Ferrara, L Califano \\ From de Senectute: Age and Health Forum \\ Catanzaro, Italy. 5-7 December 2009
}

\section{Background}

Abstract Objective. The use of bisphosphonates (zoledronic acid) in the treatment of metastatic bone disease and osteoporosis has been raised during recent years. The purpose of this treatment is mainly to reduce skeletal-related events, e.g. pain and pathological fractures. Bisphosphonate-related osteonecrosis of the jaw. (BRONJ) adversely affects the quality of life, producing significant morbidity in afflicted patients. BRONJ can develop spontaneously or after minor trauma. In general, these patients seem to have less severe manifestations of necrosis and respond more readily to stagespecific treatment regimens (Table 1). Strategies for the treatment of patients with, or at risk of, BRONJ we reset forth in the American Association of Oral and Maxillofacial Surgeons (AAOMS) Position Paper on Bisphosphonate-Related Osteonecrosis of the Jaws (Position Paper) and approved by the Board of Trusteesin September $2006 .{ }^{1}$ This update contains revisions to the diagnosis and staging and management strategie sand highlights the status of basic science research. We to report the incidence of bisphosphonate-related osteonecrosis of the jaw (ONJ), since the initiation of a routine maxillofacial examination before treatment with bisphosphonates, no ONJ has been seen.

\section{Conclusions}

$\mathrm{ONJ}$ is a rare but a very serious complication in relation to treatment with bisphosphonates. To decrease the incidence of ONJ, a maxillofacial examination could be

Department of Oral and Maxillofacial Surgery, Federico II University, Naples, 80131, Italy performed in all patients before treatment with bisphosphonates.

Published: 19 May 2010

\section{Reference}

1. Advisory Task Force on Bisphosphonate-Related Osteonecrosisof the Jaws, American Association of Oral and MaxillofacialSurgeons position paper on bisphosphonate-related osteonecrosisof the jaws. J Oral Maxillofac Surg 2009, 67:2-12.

doi:10.1186/1471-2318-10-S1-A56

Cite this article as: Ferrara and Califano: Current perspectives in the management of patients with drug-induced osteonecrosis of the maxilla: experience of the school of Naples Federico II. BMC Geriatrics 2010 10(Suppl 1):A56.
Submit your next manuscript to BioMed Central and take full advantage of:

- Convenient online submission

- Thorough peer review

- No space constraints or color figure charges

- Immediate publication on acceptance

- Inclusion in PubMed, CAS, Scopus and Google Scholar

- Research which is freely available for redistribution

Submit your manuscript at www.biomedcentral.com/submit
Biomed Central 
Table 1 Staging and treatment strategies

\begin{tabular}{|c|c|c|}
\hline $\begin{array}{l}\text { BRONJ* } \\
\text { Stage }\end{array}$ & Description & Treatment Strategies $¥ \S$ \\
\hline $\begin{array}{l}\text { At risk } \\
\text { category }\end{array}$ & $\begin{array}{l}\text { No apparent necrotic bone in patients who have been treated with either oral or IV } \\
\text { bisphosphonates }\end{array}$ & $\begin{array}{l}\text { No treatment indicated Patient } \\
\text { education }\end{array}$ \\
\hline Stage 0 & No clinical evidence of necrotic bone, but nonspecific clinical findings and symptoms & $\begin{array}{l}\text { Systemic management, including use } \\
\text { of pain medication and antibiotics }\end{array}$ \\
\hline Stage 1 & Exposed and necrotic bone in asymptomatic patients without evidence of infection & $\begin{array}{l}\text { Antibacterial mouth rinse } \\
\text { Clinical follow-up on quarterly basis } \\
\text { Patient education and review of } \\
\text { indications for continued } \\
\text { bisphosphonate therapy }\end{array}$ \\
\hline Stage 2 & $\begin{array}{l}\text { Exposed and necrotic bone associated with infection as evidenced by pain and erythema in } \\
\text { region of exposed bone with or without purulent drainage }\end{array}$ & $\begin{array}{l}\text { Symptomatic treatment with oral } \\
\text { antibiotics } \\
\text { Oral antibacterial mouth rinse } \\
\text { Pain control } \\
\text { Superficial debridement to relieve soft } \\
\text { tissue irritation }\end{array}$ \\
\hline Stage 3 & $\begin{array}{l}\text { Exposed and necrotic bone in patients with pain, infection, and one or more of the following: } \\
\text { exposed and necrotic bone extending beyond the region of alveolar bone, (ie, inferior border } \\
\text { and ramus in the mandible, maxillary sinus and zygoma in the maxilla) resulting in pathologic } \\
\text { fracture, extraoral fistula, oral antral/oral nasal communication, or osteolysis extending to the } \\
\text { inferior border of the mandible or the sinus floor }\end{array}$ & $\begin{array}{l}\text { Antibacterial mouth rinse } \\
\text { Antibiotic therapy and pain control } \\
\text { Surgical debridement/resection for } \\
\text { longer term palliation of infection and } \\
\text { pain }\end{array}$ \\
\hline
\end{tabular}

Abbreviations: BRONJ, bisphosphonate-related osteonecrosis of the jaw; IV, intravenous.

*Exposed bone in maxillofacial region without resolution within 8-12 weeks in persons treated with bisphosphonate who have not undergone radiotherapy to jaws.

tRegardless of disease stage, mobile segments of bony sequestrum should be removed without exposing uninvolved bone;extraction of symptomatic teeth within exposed, necrotic bone should be considered because it is unlikely that extraction will exacerbate established necrotic process.

fDiscontinuation of IV bisphosphonates has shown no short-term benefit. However, if systemic conditions permit,long-term discontinuation might be beneficial in stabilizing established sites of BRONJ, reducing risk of new site development,and reducing clinical symptoms. Risks and benefits of continuing bisphosphonate therapy should be made only by treating oncologist in consultation with oral and maxillofacial surgeon and patient.

$\S$ Discontinuation of oral bisphosphonate therapy in patients with BRONJ has been associated with gradual improvement in clinical disease. Discontinuation of oral bisphosphonates for 6-12 months may result in either spontaneous sequestration or resolution after debridement surgery. If systemic conditions permit, modification or cessation of oral bisphosphonate therapy should be done in consultation with treating physician and patient. 